\title{
Nanokil/Polimer/Bitüm Nanokompozit Hazırlama Yönteminin Asfalt Karıșım Performansı Üzerindeki Etkilerinin Araştırılması
}

\author{
Erol ISSKENDER ${ }^{1}$ \\ Atakan AKSOY ${ }^{2}$
}

ÖZ

$\mathrm{Bu}$ çalışmanın amacı, nanokil/polimer/bitüm nanokompozitlerin üretim süreçlerinin asfalt karışım performansı üzerindeki etkilerini araştırmaktır. Çalışmada nanokil (NC) ile stiren bütadiyen stiren (SBS) elastomerik polimeri ve etilen vinil asetat (EVA) plastomerik polimerleri katılma önceliği değiştirilerek bitüme ilave edilmiştir. Polimer modifiye asfalt nanokompozitlerle üretilen asfalt karışımlar dolaylı çekme mukavemeti, modifiye Lottman yöntemi, tekrarlı sünme deneyi ve Fransız tekerlek izi testleri ile değerlendirilmiştir. EVA/nanokil/bitüm nanokompozitler için öncelikle EVA polimerinin eklenmesi durumunda su hasarı, deformasyon ve çatlama dirençlerinde artış gözlenmiştir. SBS'li nanokompozitler kullanıldığında önce nanokil ilavesi genelde daha iyi sonuçlar vermiştir.

Anahtar Kelimeler: Asfalt karışım, nanokompozit, polimer, su hasarı, tekerlek izi, çatlama.

\section{ABSTRACT \\ Investigation of the Effects of Nanoclay/Polymer/Bitumen Nanocomposite Preparation Method on Asphalt Mixture Performance}

The aim of this study is to investigate the effects of the production processes of nanoclay/polymer/bitumen nanocomposites on the performance of the asphalt mixture. In the study, styrene butadiene styrene (SBS) and ethylene vinyl acetate (EVA) with nanoclay (NC) were added to the bitumen by changing the priority of adding. Asphalt mixtures produced with polymer modified asphalt nanocomposites were evaluated by indirect tensile strength, modified Lottman method, repeated creep test and LCPC French rutting test. For EVA/nanoclay/bitumen nanocomposites, when EVA polymer was added to bitumen before

\footnotetext{
Not: Bu yazı

- Yayın Kurulu'na 11 Şubat 2020 günü ulaşmıştır. 28 Eylül 2020 günü yayımlanmak üzere kabul edilmiştir.

- 31 Temmuz 2021 gününe kadar tartışmaya açıktır.

- https://doi.org/10.18400/tekderg.686346
}

1 Karadeniz Teknik Üniversitesi, İnşaat Mühendisliği Bölümü, Trabzon - eiskender@ktu.edu.tr https://orcid.org/0000-0001-7934-839X

2 Karadeniz Teknik Üniversitesi, İnşaat Mühendisliği Bölümü, Trabzon - aaksoy@ktu.edu.tr https://orcid.org/0000-0001-5232-6465 
nanoclay, higher water damage, cracking and deformation resistances were obtained. For $\mathrm{SBS} /$ nanoclay/bitumen nanocomposites, better results were revealed by adding NC before.

Keywords: Asphalt mixture, nanocomposite, polymer, water damage, deformation.

\section{GíRiș}

Asfalt kaplamalar servis ömrü süresince ağır ve tekrarlı trafik yükleri ile doğal çevre koşullarının etkilerine maruz kalmaktadır. Sanayi ve teknolojinin gelişmesi ile daha fazla taşımacılığa ihtiyaç duyulması, nüfusun ve hareketliliğin artması, trafiğe çıkan araç sayısının yükselmesi gibi nedenlerle yükleme koşulları her geçen gün daha da ağırlaşmakta, buna bağlı olarak da asfalt kaplamaların performansının yükseltilmesi gerekmektedir [1].

Modifiye bitümler, asfalt karışımlarının uzun dönem performansını arttırırken, kaplama bozulmalarını azaltmada önemli rol oynamaktadırlar. Modifiye bitüm üretiminde çeşitli modifikasyon katkıları kullanılabilse de polimerler en çok tercih edilen katkı maddelerinin başında yer almaktadır. Polimer modifikasyonu, bitümlü bağlayıcının fiziksel ve reolojik özelliklerini iyileştirmede etkili bir yöntem olarak sunulmaktadır [2-6].

Polimer modifiye bitüm kullanımı ile asfalt kaplamanın yorulma direnci artarken çatlama ve tekerlek izi oluşum potansiyeli azalmaktadır. Polimer katkı maddeleri stiren / bütadiyen, doğal ve kırıntı kauçukları içeren elastomerik polimerler ve polipropilen ve polietilen gibi plastomerik polimerler olmak üzere iki ana gruba ayrılmaktadırlar [3]. Asfalt kaplama performansının iyileştirilmesinde stiren-bütadiyen-stiren (SBS) ve etilen vinil asetat (EVA) en çok tercih edilen elastomerik ve plastomerik polimerlerdir [4]. Yine de bitüm ile polimer arasındaki uyumsuzluktan kaynaklanabilen depolama stabilitesi gibi problemlerden dolay1 polimerlerinin mükemmel olarak nitelendirilebilecek performans göstermedikleri ifade edilmektedir [5-6].

Son zamanlarda, bitümün modifiye edilmesindeki problemler nedeni ile polimerler yanında ikincil malzemeler de kullanılmaya başlanmıştır. Karbon nanotüp, titanyum dioksit, nanokil (organik montmorillonit), nanokalsiyumtrioksokarbonat, nanosilikon oksit ve nanoçinko oksit bu alanda üzerinde çalışılmaya başlanan nano malzemelerdir. Bitüm modifikasyonu için nanomalzeme/polimer kompozit modifikasyonu polimer modifikasyonuna en iyi alternatif olarak sunulmaktadır [7]. Nanomalzeme/polimer/bitüm kompoziti, polimer modifiye asfalt nanokompozit (PMAN) olarak adlandırılmaktadır. Asfalt karışımlarda polimer modifiye asfalt nanokompozit kullanımı nanomalzeme ve polimer miktarını azaltılabileceğinden dolayı genellikle daha ekonomik olarak değerlendirilmektedir [8]. Nanokiller maliyet-etkin oluşları ve kolay elde edilebildiklerinden daha çok tercih edilmektedirler [8-9].

SBS'in yapısı, camsı stiren yapılarının esnek bütadiyenik fazda dağıldığı ve fiziksel bir elastomerik ağın birleştirdiği, iki fazlı, uyumlu olmayan bloklardan oluşur. Asfalt ile karıştırıldığında, maltenlerin emilmesiyle SBS şişerek uzaysal bir ağ oluşumu sağlanır. Bununla birlikte SBS'in mikro yapısı korunur. Organik kökenli nanoparçacıklar, bitümlü bağlayıcının termo mekanik özelliklerini geliştirmek, bariyer özelliklerini (su geçirmez asfalt durumunda) iyileştirmek için polimer matrisine eklenebilmektedirler. Nanokil ilavesi ile polimerlerin de özellikleri geliştirilebilmektedir. Nanopartikül/polimer modifikasyonunun başarısı nano partiküllerin karakterine, boy-en oranına, organik modifiye ediciye, polimerik 
matrise ve modifikasyon sürecine bağlıdır [10]. Polimer modifiye asfalt nanokompozitlerde nanokilin varlığı, polimer ile bitüm yoğunluğu arasındaki farkı azaltmakta, depolama stabilitesini ve bitüm-polimer arasındaki uyumu arttırmaktadır [11].

Katmanlı silikatlar, polimer modifiye bitümdeki farklı fazları birbirine bağlamak için yüzey aktif madde olarak kullanılmaktadır. PMAN içinde nanotabakaların dağılımında, polimer zincirlerinin nanokil katmanlarının ara tabakasına girmesiyle belirgin bir gelişme kazanılmaktadır. Nanokil malzemesi asfalt ve polimer arasında uyumlaştırıcı gibi etki göstermektedir. Nanokil polimer ile daha fazla etkileşime girdiğinde, daha iyi bir dağılıma yol açarak morfolojik ve reolojik özellikleri etkilemektedir [12]. PMAN için istenilen morfolojinin elde edilmesinde modifikasyon yöntemi anahtar parametredir [13-15]. Karışım tasarımından önce bu tür bireysel sistemlerin çalışılması önemlidir. Çeşitli yöntemler olmakla beraber sıcak ekleme ve çözelti yöntemi bitüm modifikasyonunda daha çok tercih edilmektedir. Çözelti yönteminde silikatları şişirebilen ve polimeri çözen çözücüler kullanılır. Bu şekilde, zayıf ara tabaka kuvvetlerine sahip katmanlı silikatlar kolayca dağılır ve polimer zincirleri, silikat ara katmanındaki çözücünün yerini alır. Elde edilen çözelti bitüme ilave edildikten sonra ısıtılarak çözücü buharlaştırıldığında, PMAN elde edilmiş olur. Sıcak ekleme yönteminde ise bitüm ve polimerin eriyebileceği bir sıcaklığa kadar (genellikle $150^{\circ} \mathrm{C}-180^{\circ} \mathrm{C}$ sıcaklık aralığı) 1sıtma yapıldıktan sonra yüksek kesme etkili mikser ile nanokil ve polimer doğrudan bitüme ilave edilir, ya da önce nanokil/polimer birlikteliği kurulur ve daha sonra bitüme ilave edilerek nanokompozit oluşturulur [10].

Polimer nanokompozitler, temel olarak en az bir polimerin nanokil ve karbon nanotüp gibi çeşitli nanomalzemeler ile belirli koşullarda karıştırılmasıyla elde edilmektedir. Polimer/kil nanokompozitler (tabakalı silikat nanokompozitler) dağılmış fazda en az bir boyutta nanometrik seviyede olan polimerin kil içerisinde dağıldığı bir sistemdir. [16-17]. Tabakalı silikat nanokompozitlerde üç tip yapısal dağılım mümkündür: faz ayrışık (mikro kompozit) (immiscible/floculated) dağılım, aralanmış (interkalasyonlu) (intercalated) dağılım ve eksfoliye (exfoliye) dağılım. Şekil 1'de mümkün dağılım türleri gösterilmiştir. Şekil 1'de birinci satırda elektron mikroskobu görüntüleri ikinci satırda ise silikat tabakaları ve polimer matrisi şematik olarak görülmektedir. Görüntülerde koyu renkli bölgeler silikat tabakalarını göstermektedir. Eksfoliye nanokompozitlerde bireysel kil tabakaları sürekli polimer fazı içerisinde dağılır ve kil yüküne bağlı bir mesafede yerleşir. Kil tabakaları düzensiz bir yapıda homojen dağılır. İnterkalasyonlu yapılarda polimer kil tabakaları arasına girer fakat kil tabakaları tamamen dağılmaz. Tabakalar arasında önemli bir etkileşim vardır ancak tamamen eksfoliye bir yapı gözlenmez. Faz ayrışık nanokompozitlerde ise hidroksillenmiş uçların etkileşiminden dolayı polimer kil katmanları arasına giremez ve bazı silikat tabakaları polimer matrisi içerisinde kümeler halinde dağılır. Bu dağılım şekli ayrışık faz görünümünü oluşturur [18]. Eksfoliye nanokompozitler, diğer yapılara kıyasla daha iyi fiziksel özelliklere sahip malzemelerdir [19].

Polimer modifiye bitümlere (PMB) üçüncü bileşen olarak nispeten daha az miktarlarda nanokilin eklenmesinin etkisinin değerlendirildiği bir çalışmada bitüm/nanokil ve polimer/nanokil etkileşimleri kurularak polimer ve nanokil ayrı ayrı ve mastır karışım hazırlanarak bir arada bitüme ilave edilerek araştırılmıştır. Çalışma sonuçları, polimer modifiye asfalt nanokompozitin reolojik davranışının bu hazırlanma yönteminden ve bileşenlerin eklenme sırasından önemli derecede etkilendiğini göstermektedir [20]. Asfalt bağlayıcıların mekanik özelikleri üzerinde, bitüm ağırlığına göre \%2-\%4 oranlarında nanokil 
ilavesinin etkisinin araştırıldığ 1 bir çalışmada polimer modifiye bitümlere üçüncü bileşen olarak nanokil ilavesinin tekerlek izi direncini ve düşük sıcaklık çatlama dirençlerini arttırdığı ancak karıştırma prosedürlerinin çok önemli olduğu vurgulanmıştır [3]. Modifikasyon işleminde bileşenlerin ilave edilme sırası, PMAN üretim sürecinde uygun sıralamanın tam olarak anlaşılması için araştırılması gereken bir konu olarak değerlendirilmektedir [21].

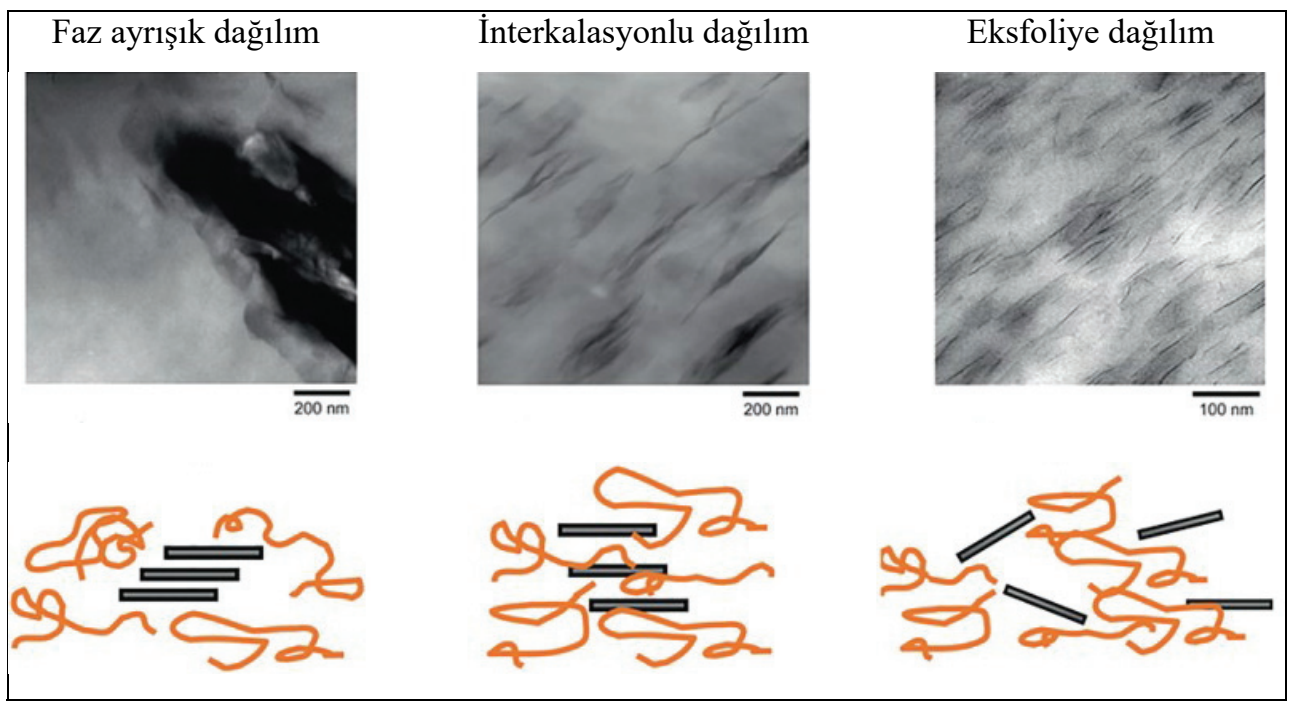

Şekil 1 - Polimer/tabakalı silikat nanokompozitlerde farklı dă̆llım tiplerinin gösterimi [19]

Literatürde, PMAN hazırlama sürecinde nanokil ve polimerlerin bitüme ilave edilme sırasının nihai asfalt karışım performansına etkisinin araştırıldığı yeterince çalışma bulunmamaktadır. Mevcut çalışmalar çoğunlukla modifiye bitümün özelliklerinin değerlendirilmesine odaklandırılmıştır. PMAN kullanılarak hazırlanan asfalt karışımların nihai performanslarının nanokompozit hazırlama yöntemine bağlı olarak araştırılması önemli bir konu olarak görülmektedir. Bu çalışmanın amacı, elastomerik (SBS) ve plastomerik (EVA) polimerler kullanılarak sıcak ekleme yöntemi ile asfalt nanokompozit üretiminde nanokil ve polimer ilave edilme sırasının nihai asfalt karışımın mekanik özellikleri üzerindeki etkilerinin araştırılmasıdır. Polimerlerin ve nanokilin bitüme katılma sıraları değiştirilerek üretilen modifiye bitümlü karışımlar modifiye Lottman yöntemi, tekrarlı yük sünme deneyi, Fransız tekerlek izi deneyi ve dolaylı çekme mukavemeti deneyi ile değerlendirilmiştir.

\section{MATERYAL}

\subsection{Agrega}

Yüksek durabilite, düşük permeabilite, düşük trafik gürültü kirliliği, yansıma çatlaklarına ve tekerlek izlerine karşı yüksek direnç sağlamasından dolayı taş mastik asfalt karışımlar tercih konusu olmaktadır [22]. Çalışmada bazalt agregası kullanılarak karayolları teknik 
Tablo 1 - Bazalt agregasının mühendislik özellikleri

\begin{tabular}{|c|c|c|c|}
\hline Özellik & Deney & Değer & Şartname limiti \\
\hline Özgül ağırlık (Kaba agrega) & ASTM C 127 & & \\
\hline Hacim & & 2.684 & \\
\hline Zahiri & & 2.744 & \\
\hline Özgül ağırlık (İnce agrega) & ASTM C 128 & & \\
\hline Hacim & & 2.656 & \\
\hline Zahiri & & 2.754 & \\
\hline Özgül ağırlık (filler) & & 2.821 & \\
\hline \multicolumn{4}{|l|}{ Kaba agrega özellikleri } \\
\hline Parçalanma direnci (Los Angeles), (\%) & TS EN 1097-2 & 12 & $\leq 25$ \\
\hline $\begin{array}{l}\text { Hava tesirlerine karşı dayanıklılık } \\
\left(\mathrm{MgSO}_{4} \text { ile kayıp), \% }\right.\end{array}$ & TS EN 1367-2 & 8 & $\leq 14$ \\
\hline Yassılık indeksi (\%) & BS 812 & 14 & $\leq 25$ \\
\hline Cilalanma değeri, \% & TS EN 1097-8 & 63 & $\geq 50$ \\
\hline Su emme $(\%)$ & TS EN 1097-6 & 0.81 & $\leq 2.0$ \\
\hline Kırılmışlık, ağırlıkça, \% & TS EN 933-5 & 100 & $\geq 100$ \\
\hline Kil topakları ve ufalanabilir daneler, \% & AASHTO T112 & Yok & Bulunmayacak \\
\hline
\end{tabular}

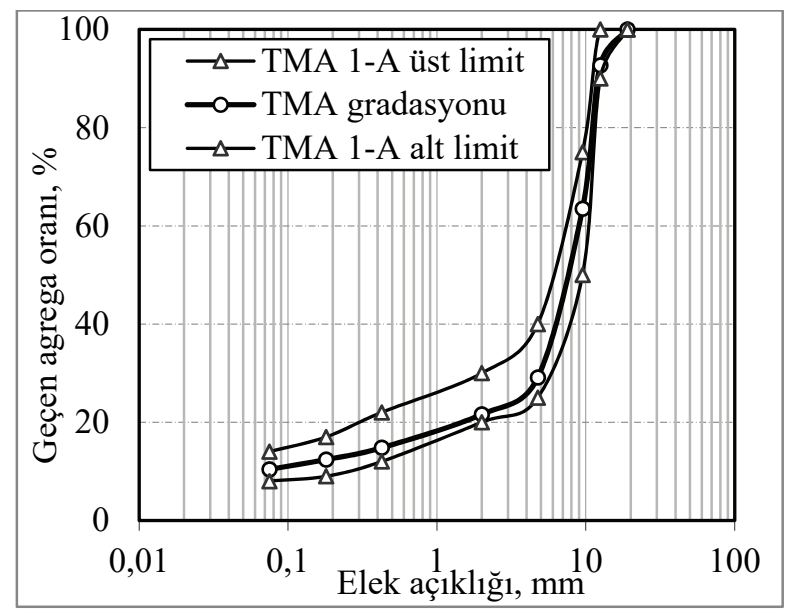

Şekil 2 - TMA için agrega gradasyon eğrisi 
şartnamesine (KTŞ 2013) [23] göre taş mastik asfalt (TMA) Tip 1 A tasarımı yapılmıştır. Agregaların mühendislik özellikleri ve agrega gradasyonu Tablo 1 ve Şekil 2'de gösterilmiştir. Kaba agrega oranı \%70.9, ince agrega oranı $\% 18.7$ ve filler oranı da \%10.4 olarak oluşmuştur. Tablo 1'den agrega özelliklerinin şartname limitlerine uygun olduğu görülmektedir.

\subsection{Asfalt Çimentosu}

Asfalt çimentosu olarak geleneksel test sonuçları Tablo 2'de verilen 50/70 penetrasyon dereceli bitümlü bağlayıcı kullanılmıştır.

Tablo 2 - Saf ve modifiye bitümlerin temel özellikleri

\begin{tabular}{llllll}
\hline Test & Test Yöntemi & Birim & $\begin{array}{l}\text { Saf } \\
\text { bitüm }\end{array}$ & $\begin{array}{l}\text { Nanokil } \\
\text { modifiye bitüm }\end{array}$ & $\begin{array}{l}\text { SBS modifiye } \\
\text { bitüm }\end{array}$ \\
\hline Özgül ağırlık $\left(25^{\circ} \mathrm{C}\right)$ & TS EN 15326 & $\mathrm{gr} / \mathrm{cm}^{3}$ & 1.025 & 1.027 & 1.017 \\
Yumuşama noktası & TS EN 1427 & ${ }^{\circ} \mathrm{C}$ & 52 & 57 & 64 \\
Penetrasyon $\left(25^{\circ} \mathrm{C}\right)$ & TS EN 1426 & $0.1 \mathrm{~mm}$ & 63 & 60 & 56 \\
Düktilite $\left(25^{\circ} \mathrm{C}\right)$ & TS EN 12592 & $\%$ & 99.6 & 96.3 & $100+$ \\
\hline
\end{tabular}

\subsection{Katkı Maddeleri}

SBS elastomeri (Kraton D1192 ESM) ve EVA plastomeri (ELVAX 420) polimer katk1 maddeleri olarak kullanılmıştır. SBS ve EVA katkılarının üretici firma verileri sırasıyla Tablo 3 ve Tablo 4'te verilmiştir. Bitüm modifikasyonu için optimum polimer oranı literatürde \%4-\%6 aralığında önerilmektedir. Katk1 maddesi oranı \%6'nın üzerine çıkarıldığında, modifiye bitüm özelliklerinde kayda değer bir kazanç sağlanamadığı belirtilmektedir [24]. Bu çalışmada, her iki polimer de ağırlıkça \%5 oranında kullanılmıştır.

Tablo 3 - SBS katkı maddesinin genel özellikleri [25].

\begin{tabular}{ll}
\hline Özellik & Değer \\
\hline Moleküler yapı & Lineer \\
Moleküler ağırlık, kg/mol & $138-162$ \\
Polistiren içeriği, \% & $28.5-32.5$ \\
Vinil içeriği, \% & $\geq 35$ \\
Triblok içeriği & $\geq 90$ \\
Uçucu madde, \% & $\leq 0.3$ \\
Antioksidan içeriği, \% & $\geq 0.16$ \\
Özgül ağırlık, gr/cm ${ }^{3}$ & 0.94 \\
Erime akış hızı, $200^{\circ} \mathrm{C} / 5 \mathrm{~kg}, \mathrm{~g} / 10 \mathrm{dak}$. & $<1$ \\
Kopma uzaması, $\%$ & 1000 \\
Çekme mukavemeti, MPa & 33 \\
\hline
\end{tabular}


Modifikasyonun etkisini arttırmak için, SBS ve EVA katkılarına ek olarak bentonit kilinden üretilen nanokil (esanNANO 1-140) (NC) bitüme ilave edilerek asfalt nanokompozitler oluşturulmuştur. Nanokil katkı maddesi Eczacıbaşı Esan firması tarafından Demirli bentonitinden üretilmiştir. Saflaştırma süreci killerin su ile açıldıktan sonra 32 mikronluk elekten elenmesi ve filter preslerden süzülmesi şeklinde gerçekleştirilmiştir. Hidrosiklon ile saflaştırılan kil sodyum ile aktivasyon edildikten sonra tekrar öğütülmüştür. Na-aktive saflaştırılmış kilin yüzey modifikasyonu "dimethyl dehydrogenated tallow quaternary ammonium" organik modifiye edici ile yapılmıştır. Hidrosiklon ile saflaştırma ve sodyum aktivasyon akış şemaları Şekil 3 ve Şekil 4'te gösterilmiştir. Nanokilin kimyasal analiz sonuçları Tablo 5'te, taramalı Elektron Mikroskobu (SEM) görüntüsü ve lazer difraktometresi ile yapılan boyut analizi Şekil 5 ve Şekil 6'da verilmiştir. Nanokilin tabakalar arası mesafesi X ışını difraktometresi ile 38.62A olarak ölçülmüştür. Birim yüzey alanı ise $2512 \mathrm{~m}^{2} / \mathrm{kg}$ olarak belirlenmiştir. Nanokilin nano boyutlara ulaştığ ağırlıkça \%3 oranında kullanılmıştır. Süzülme önleyici katkı maddesi olarak ta selülozik elyaf \%o3 oranında agrega karışımına ilave edilmiştir.

Tablo 4 - EVA katkı maddesinin genel özellikleri [26].

\begin{tabular}{ll}
\hline Özellik & Değer \\
\hline Yoğunluk, gr $/ \mathrm{cm}^{3}$ & 0.937 \\
Vinil asetat komonomer içeriği, \% & 18 (kütlece) \\
Erime akış hızı, $190^{\circ} \mathrm{C} / 2.16 \mathrm{~kg}, \mathrm{~g} / 10 \mathrm{dak}$. & 150 \\
Erime noktası, ${ }^{\circ} \mathrm{C}$ & 73 \\
Donma noktası, ${ }^{\circ} \mathrm{C}$ & 53 \\
Maksimum işleme sicaklığ $1,{ }^{\circ} \mathrm{C}$ & 235 \\
Termal stabilizer & bütil hidroksi toluen \\
\hline
\end{tabular}

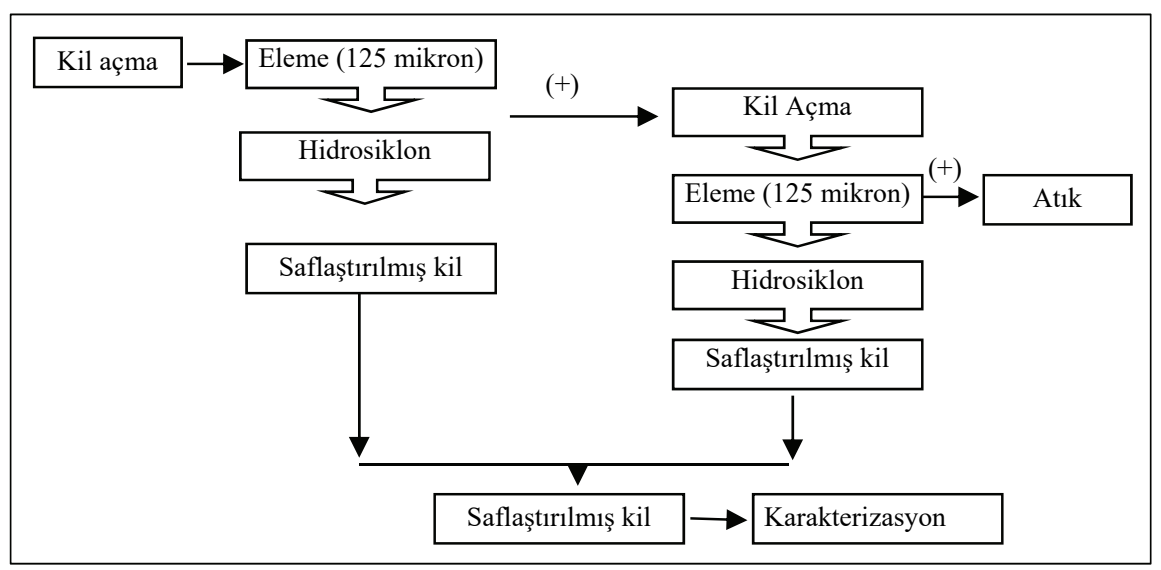

Şekil 3 - Eleme ve hidrosiklon ile saflaştırma akışşeması 


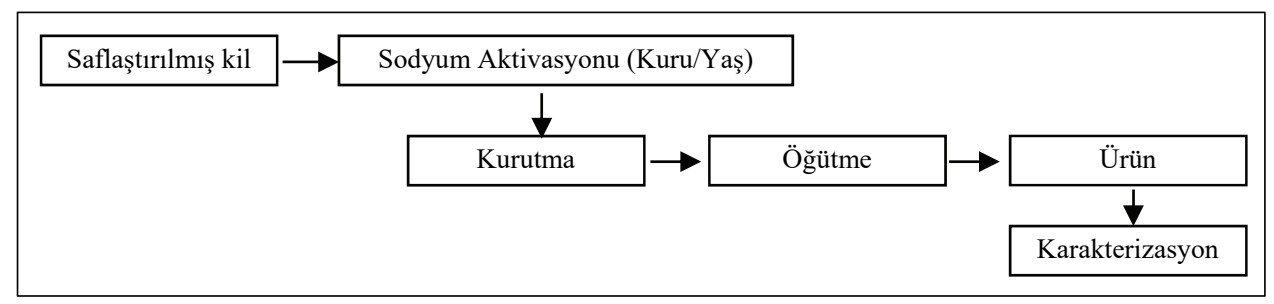

Şekil 4 - Sodyum aktivasyonu akış diyagramı

Tablo 5 - Kullanılan nanokilin anaoksit içerikleri [27]

\begin{tabular}{llll}
\hline Oksit ad 1 & İçerik $(\%)$ & $\mathrm{Oksit}_{1}$ & İçerik $(\%)$ \\
\hline $\mathrm{Al}_{2} \mathrm{O}_{3}$ & 8.394 & $\mathrm{Nb}_{2} \mathrm{O}_{5}$ & 0.005885 \\
$\mathrm{CaO}$ & 0.1531 & $\mathrm{NiO}$ & 0.01105 \\
$\mathrm{Cl}$ & 0.4869 & $\mathrm{P}_{2} \mathrm{O}_{5}$ & 0.008532 \\
$\mathrm{CuO}$ & 0.007995 & $\mathrm{Rb}_{2} \mathrm{O}$ & 0.002243 \\
$\mathrm{Fe}_{2} \mathrm{O}_{3}$ & 0.5189 & $\mathrm{SO}_{3}$ & 0.04875 \\
$\mathrm{GeO}_{2}$ & 0.003939 & $\mathrm{SiO}_{2}$ & 42.99 \\
$\mathrm{~K}_{2} \mathrm{O}$ & 0.1672 & $\mathrm{TiO}_{2}$ & 0.04296 \\
$\mathrm{MgO}$ & 2.174 & $\mathrm{ZnO}$ & 0.007696 \\
$\mathrm{MnO}$ & 0.01927 & $\mathrm{ZrO}_{2}$ & 0.004362 \\
$\mathrm{Na}_{2} \mathrm{O}$ & 0.2342 & $\mathrm{~K}_{12 d}$ & 44.72 \\
\hline
\end{tabular}

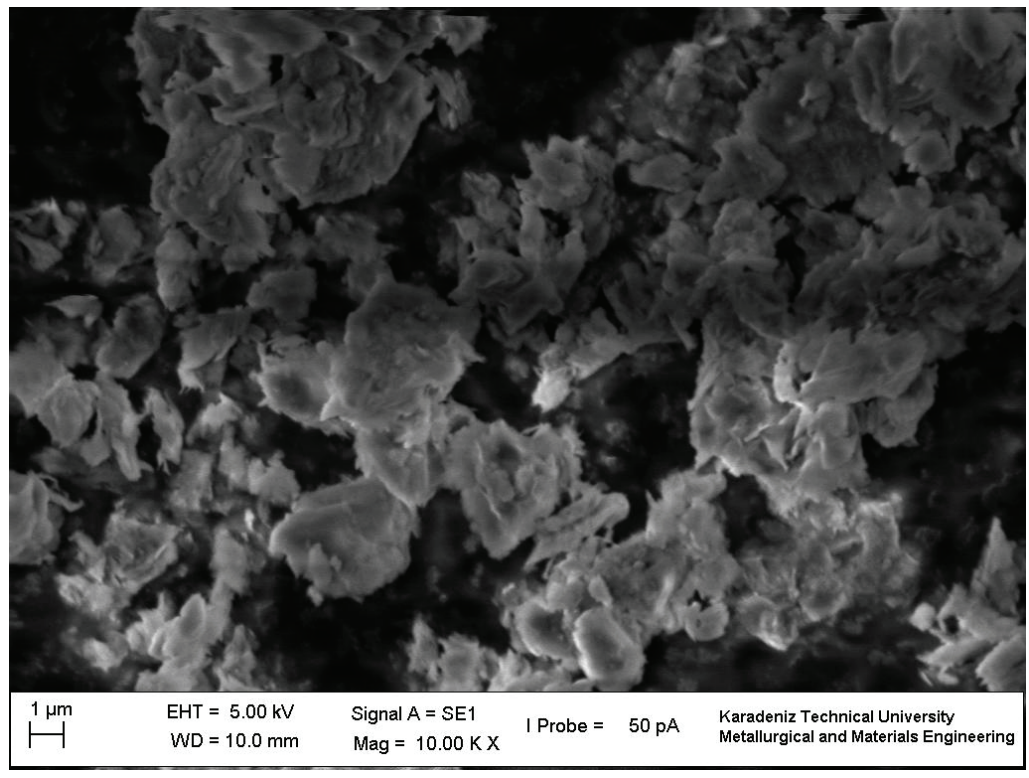

Şekil 5 - Nanokil katkısının SEM görüntüsü [27] 


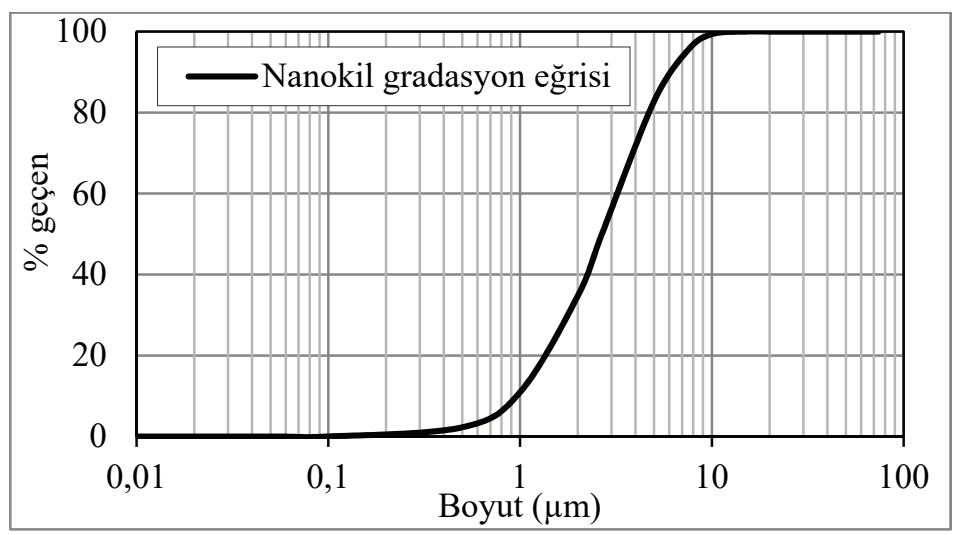

Şekil 6 - Nanokil katkı maddesinin lazer difraktometresi ile boyut analizi

\section{YÖNTEM}

\subsection{Polimer/Nanokil/Bitüm Nanokompozit (PMAN) Üretimi}

PMAN üretiminde nanokil ile birlikte SBS elastomeri ve EVA plastomeri olmak üzere iki polimer kullanılmıştır. Nanokil ve polimerin bitüme katılma sıraları değiştirilerek Nanokil/SBS ve Nanokil/EVA modifiye bitümleri üretilmiştir. Hazırlanan nanokompozitler katılma sırasına göre NC (nanokil modifiye bitüm), NC+EVA (bitüme önce nanokil sonra EVA ilave edilmiştir), EVA+NC (bitüme önce EVA sonra nanokil ilave edilmiştir), NC+SBS (bitüme önce nanokil sonra SBS ilave edilmiştir) ve SBS+NC (bitüme önce SBS sonra nanokil ilave edilmiştir) adlandırılarak kontrol bitüm ile birlikte asfalt karışım örneği hazırlamada kullanılmıştır. Son yıllarda, nanokil modifiye bitüm üretiminde seçilen modifikasyon değişkenlerinin değerlendirildiği çalışmada modifikasyon parametrelerinin çok değişken olduğu, bununla birlikte literatürde yer alan çalışmalarda karıştırma sıcaklıklarının $150^{\circ} \mathrm{C}$ ile $160^{\circ} \mathrm{C}$ aralığında, karıştırma hızının $4000 \mathrm{rpm}-5000 \mathrm{rpm}$ aralığında yoğunlaştığı belirtilmektedir. Yine aynı çalışmadan, ifade edilen sıcaklık ve karıştırma hızı seviyelerinde karıştırma sürelerinin genellikle 40-60dk olarak uygulandığı, nanokil oranının çoğunlukla \%3 olarak seçildiği görülmektedir [18]. Bir diğer çalışmada, nanokil oranının ağırlıkça \%3 oranının üzerine çıkarılması durumunda eksfoliye dağılımın sağlanamayabileceği [28] ve nanokompozitin özelliklerinin olumsuz etkilenebileceği [29] ifade edilmektedir. Önceki tecrübelerden [27] yüksek nanokil oranının (\%5) mekanik deney sonuçlarında tutarsızlığa neden olduğu anlaşılmış, bu çalışmada nanokil ağırlıkça \%3 oranında kullanılmıştır.

Modifikasyon yüksek kesme etkili mikserde, $155^{\circ} \mathrm{C}$ sıcaklıkta, 5000rpm karıştırma hızında her bir katkı maddesi için 20 dakika olmak üzere toplam 40 dakika süre ile uygulanmıştır. İkinci katkı maddesinin ilavesine, karıştırmaya ara verilmeden devam edilmiştir. Karşılaştırma yapabilmek için bitüme yalnızca nanokil ilave edilen seçenekte 40 dakika karıştırma yapılmıştır. Modifiye bitüm üretimi $1500 \mathrm{gr}$ bitüm kullanılarak yapılmıştır.

Asfalt karışım tasarımı Marshall tasarım metoduna göre kontrol bitüm ile yapılmıştır. Optimum bitüm içeriği \%3 hava boşluğunu veren bitüm oranı olarak alınmış ve \%6.1 olarak 
bulunmuştur. Asfalt karışımların karıştırma ve sıkıştırma sıcaklıkları Karayolları Teknik Şartnamesine (KTŞ 2013) [23] uygun olarak yapılmıştır. Modifiye bitümler $155^{\circ} \mathrm{C}$ ve agregalar $175^{\circ} \mathrm{C}$ sıcaklıkta isıtılarak karışım hazırlanmıştır. Sıkıştırma işlemi $145^{\circ} \mathrm{C}$ sıcaklıkta, briketin her iki yüzeyine 50 darbe uygulanarak yapılmıştır. Optimum bitüm içeriğinde kontrol ve modifiye bitümler ile bitümlü sıcak karışımlar üretilmiştir.

\subsection{Modifiye Lottman Deneyi}

Polimer/nanokil/bitüm nanokompozitlerle üretilen asfalt karışımların su hasarına karşı dirençleri Modifiye Lottman (AASHTO T283) [30] yöntemiyle değerlendirildi. Nicel bir test yöntemi olan AASHTO T283 metodunun asfalt karışımların sudan kaynaklanan bozulmaları değerlendirmede en etkin deney yöntemlerinden biri olduğu ifade edilmektedir [31-23]. Bu yöntem ile hem soyulma eğilimli malzemelerin belirlenebileceği hem de su hasarı önleyici katkıların etkililiklerinin saptanabileceği savunulmaktadır [34]. Deneyde, üçer örnekten oluşan koşullandırılmış ve koşullandırılmamış briket grupları kullanılmaktadır. Koşullandırılmış gruptaki örneklerin çekme mukavemetlerinin ortalaması koşullandırılmamış gruptaki örneklerin çekme mukavemetlerinin ortalamasına oranlanarak çekme mukavemeti oranı (TSR) elde edilmektedir. Daha büyük TSR değerleri asfalt karışımın su hasarına karşı daha dirençli olduğu anlamına gelmektedir. Su hasarına karşı dirençli bir karışım için en az 0.8 TSR değeri önerilmektedir [35].

\subsection{Fransız Tekerlek İzi Deneyi}

Asfalt karışımların tekerlek izi dirençleri Fransız tekerlek izi deneyi (Laboratoire Central des Ponts et Chaussées wheel tracker) ile belirlendi. Yöntem, sıkıştırılmış asfalt karışımların kalıcı deformasyon potansiyellerinin belirlenmesinde araç tekerleklerinin oluşturmuş olduğu etkiyi laboratuvarda simüle edebilmektedir. Fransa'da, ağır trafik koşullarına maruz kalan karışımları test etmekte kullanılmaktadır[36]. Deney cihazında $0.60 \pm 0.03 \mathrm{MPa}$ basınca kadar şişirilmiş, karşılıklı iki adet pnömatik kauçuk tekerlek kullanılarak 500mm uzunluğunda, $180 \mathrm{~mm}$ genişliğinde, $50 \mathrm{~mm}$ veya $100 \mathrm{~mm}$ kalınlığında briketler test edilebilmektedir. Deney sıcaklığ $130^{\circ} \mathrm{C}-70^{\circ} \mathrm{C}$ aralığında seçilebilmektedir. Bu çalışmada test sicaklığ $160^{\circ} \mathrm{C}$ ve tekerlek yükü $5000 \mathrm{~N}$ olarak uygulanmıştır. Asfalt briketleri deneye başlamadan önce 12 saat test sıcaklığında bekletilmiştir. Deney 50,000 tekerlek devir sayısı ile sonlandırılmıştır.

\subsection{Tekrarlı Yük Sünme Deneyi}

Asfalt karışımların tekerlek izi dirençleri tekrarlı yük sünme deneyi ile de değerlendirildi. Tekrarlı yük sünme deneyi uygulamada oluşan tekerlek izleri ile yüksek korelasyonlu sonuçlar verebilmektedir [37]. Deney istenilen sıcaklıkta, önceden belirlenmiş gerilme ve yükleme sayılarında yapılabilmektedir. Deneyde karot örnekleri kullanılabildiği gibi 100mm veya $150 \mathrm{~mm}$ çaplı Marshall briketleri de kullanılabilmektedir. Bu çalışmada deney sıcaklığı $40^{\circ} \mathrm{C}$, koşullandırma gerilmesi $10 \mathrm{kPa}$, koşullandırma süresi 2 dakika, test gerilmesi $100 \mathrm{kPa}$, yükleme periyodu $1000 \mathrm{~ms}$, yüklü süre $500 \mathrm{~ms}$, yüksüz süre $500 \mathrm{~ms}$ ve deneyi sonlandıran yükleme sayısı 21,600 olarak seçilmiştir. 


\subsection{Düşük Sıcaklık Dolaylı Çekme Mukavemeti Deneyi}

Asfalt betonunun çekme mukavemeti özelliği, çatlak veya deformasyon türü bozulma söz konusu olduğunda önemli bir konudur; öte yandan, asfalt betonunun durabilitesi söz konusu olduğunda, asfalt betonunun çevresel değişikliklere duyarlılığı hayati önem taşımaktadır. Dolaylı çekme mukavemeti testi, asfalt betonunda, kaplamanın daha çok çatlama özellikleri ile ilişkili olabilen çekme davranışını belirlemek için kullanılabilir [38-39]. Testin gerçekleştirilmesi kolaydır ve malzemelerin temel özellikleri bakımından karakterize edilmesinde etkili olduğu düşünülmektedir [40]. Çevre koşulları asfalt kaplamanın performansını etkileyen en önemli faktörlerden biridir. Hava sıcaklığı asfalt kaplamanın bozulmasına yol açabilir. Aşırı düşük sıcaklıklarda çatlama problemi gelişebilir ve bazı bölgelerde düşük sıcaklık çatlaması birincil bozulma türü olarak görülebilir [41].

Deney $-10^{\circ} \mathrm{C}$ sicaklıkta her seçenekten üç örneğe yapılmıştır. Deneyden önce sicaklığ1 kontrol altına alabilmek için örnekler çevresel koşullandırma kabininde, $-10^{\circ} \mathrm{C}$ sıcaklıkta 6 saat bekletildikten sonra test gerçekleştirilmiştir.

\section{DENEY SONUÇLARI VE DEĞERLENDİRME}

\subsection{AASHTO T 283 Su Hasarı Değerlendirmesi}

AASHTO T283 yöntemi asfalt karışımların su hasarına karşı direncinin belirlenmesi için bütün karışım seçeneklerine uygulanmıştır. Koşullandırılmış ve koşullandırılmamış karışımların çekme mukavemetleri Şekil 7'de ve çekme mukavemetleri oranları da Şekil 8'de verilmiştir.

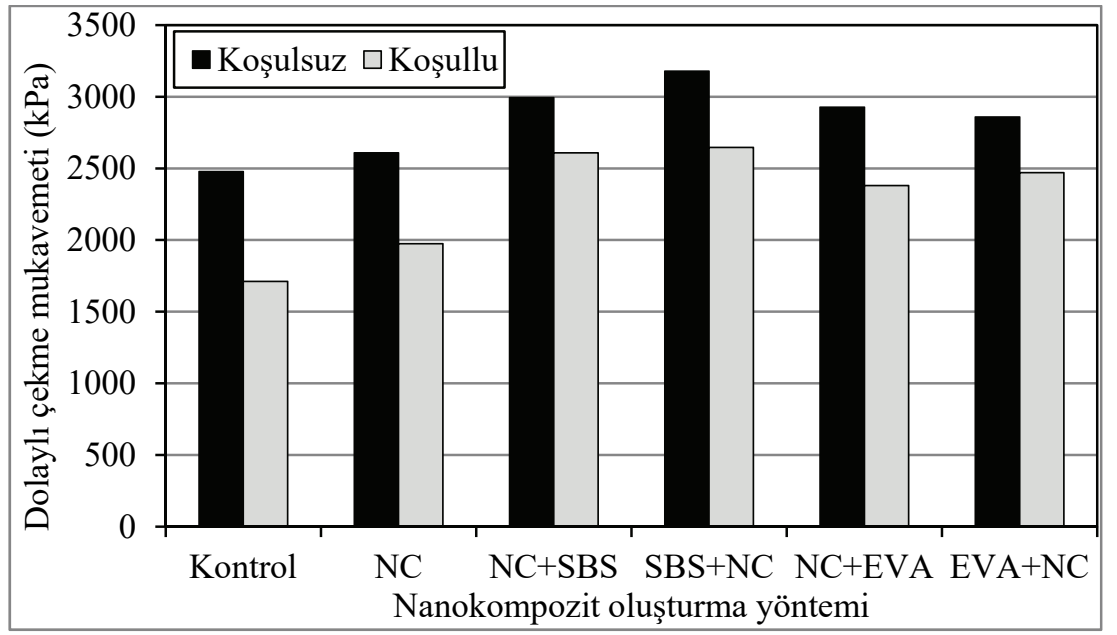

Şekil 7 - Nanokompozit oluşturma yöntemine göre koşullandırılmış ve koşullandırılmamış karışım örneklerin çekme mukavemetlerinin değişimi

Şekil 7'den, asfalt karışım örneklerinin dolaylı çekme dayanımlarının modifiye edici katkı tipinden ve nanokompozit oluşturma yönteminden etkilendiği görülmektedir. Kontrol 
karışımlar referans alındığında, bitümün nanokil ile modifiye edilmesi durumunda çekme mukavemetlerinin koșullandırılmamış örneklerde yaklaşık \%5 oranında, koşullandırılmıș örneklerde de yaklaşık \%15 oranında arttığı görülmüştür. NC katkısı, SBS ve EVA polimerleri ile ikili fayda sağlayarak yalnızca NC modifikasyonuna göre çok daha yüksek çekme mukavemeti değerleri oluşturmuştur. Modifiye Lottman koşullandırmasına tabi tutulmuş SBS içeren modifikasyonlarda kontrol karışıma göre \%50'nin üzerinde, EVA içerenlerde ise \%39'dan daha fazla dayanım artışı görülmüştür. Ancak koşullandırılmamış karışımlarda çekme mukavemetlerindeki artış azalmıştır. SBS/nanokil/bitüm seçenekleri için $\% 20$ 'den daha fazla, EVA/nanokil/bitüm seçenekleri için \%15'ten daha fazla artışlar görülmüştür. Nanokompozit hazırlama sürecinde, polimer ve nanokil katkılarının bitüme katılma sırasının nihai asfalt karışımın çekme mukavemetleri üzerinde etkili olduğu görülmüştür. SBS polimeri ile hazırlanan nanokompozitlerde, bitüme önce SBS katkısının katılması durumunda, EVA polimerinin kullanıldığı durumlarda ise önce NC katkısının eklendiği seçenekte daha yüksek çekme mukavemeti elde edilmiştir.

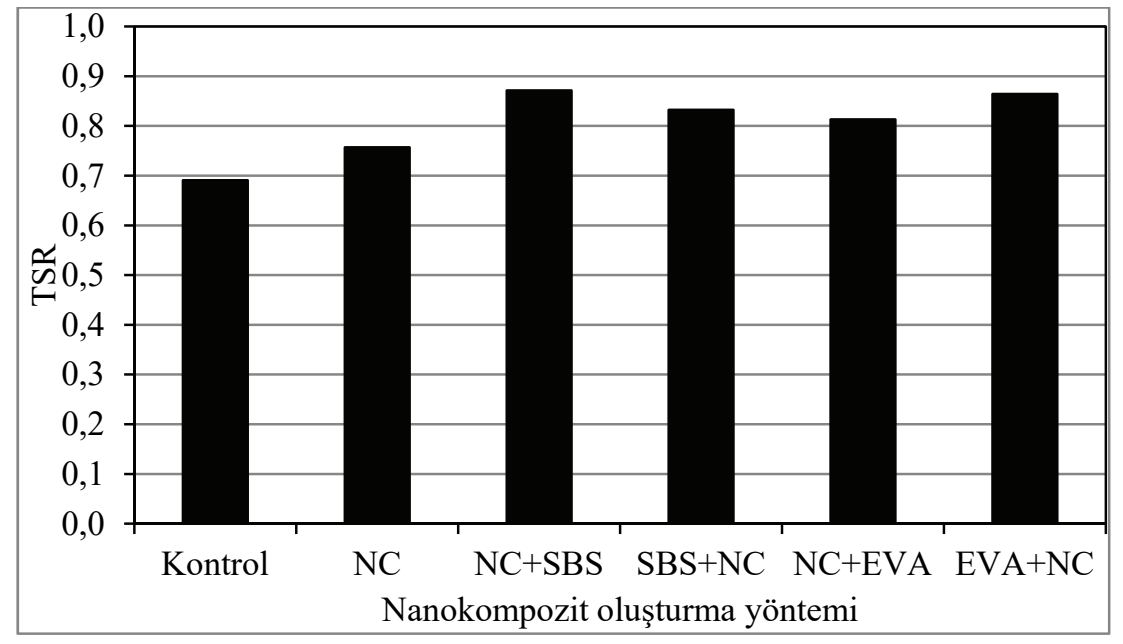

Şekil 8 - Polimer/nanokil/bitüm nanokompozit hazırlama yöntemi - TSR ilişkisi

Su hasarı direnci açısından değerlendirildiğinde (Şekil 8), NC modifikasyonunun su hasarı direncini kontrol karışımlara kıyasla yaklaşık \%10 oranında arttırdığ 1 , ancak 0.80 eşik değeri göz önüne alındığında su hasarına karşı yeterli direncin sağlanamadığı görülmüştür.

Bununla birlikte, polimer/nanokil/bitüm nanokompozitlerle hazırlanan bütün karışımlarda 0.80 TSR kriterinin sağlandığı görülmüştür. Katkılı seçeneklerin özellikle koşullandırılmış durumda kontrol karışımlara göre daha yüksek dayanımlar vermesi TSR değerlerinin artmasını sağlamıştır. Su hasarı açısından, nanokompozit oluşturma aşamasında, SBSnanokil-bitüm nanokompozitlerde bitüme önce NC'in katılmasının $\% 4$ daha yüksek TSR değeri, EVA-nanokil-bitüm nanokompozitlerde, önce EVA'nın eklenmesinin de \%5 daha yüksek TSR değeri oluşturduğu görülmüştür.

Asfalt karışımlarda nanokil modifikasyonunun su hasarı hassasiyetini iyileştirdiği bilinmektedir [42]. Nano partiküllerin polimerlerle birlikte kullanımının polimerin ve 
nanokilin sağladığı performans artışından daha fazlasını sağladığı ifade edilmektedir. Farklı oranlarda SBS ve nano- $\mathrm{SiO}_{2}$ katkılarının bitüm modifikasyonunda kullanılması yoluyla asfalt karışımların mekanik özellikleri değerlendirilmiş ve $\% 1$ nano- $\mathrm{SiO}_{2} / \% 5 \mathrm{SBS}$ kombinasyonunun en iyi performansı sergilediği görülmüştür [43]. Nanokil ve karbon mikrofiber kullanımının asfalt karışımların su hasarı direnci üzerindeki etkisinin araştırıldığı bir çalışmada, asfalt karışım örnekleri hem su hem de çeşitli konsantrasyonlardaki buzlanma önleyici çözeltiler ile yedi döngüden oluşan ağırlaştırılmış koşullandırmaya tabi tutulmuş, nanokil oranının artmasıyla koşullu örneklerin çekme mukavemetlerinin ve su hasarı direncinin arttığı görülmüştür [44].

\subsection{Tekrarlı Yük Sünme Deneyi}

Polimer ve nanokil ekleme sırası değiştirilerek hazırlanan nanokompozitlerle üretilen asfalt karışımların kalıcı deformasyon davranışları tekrarlı yük sünme deneyi ile değerlendirilmiştir. Deneylerde her seçenek için AASHTO T283 yöntemine göre koşullanmış üç Marshall briketi kullanılmıştır. Deneyden elde edilen sünme deformasyonu eğrileri Şekil 9'da verilmiştir.

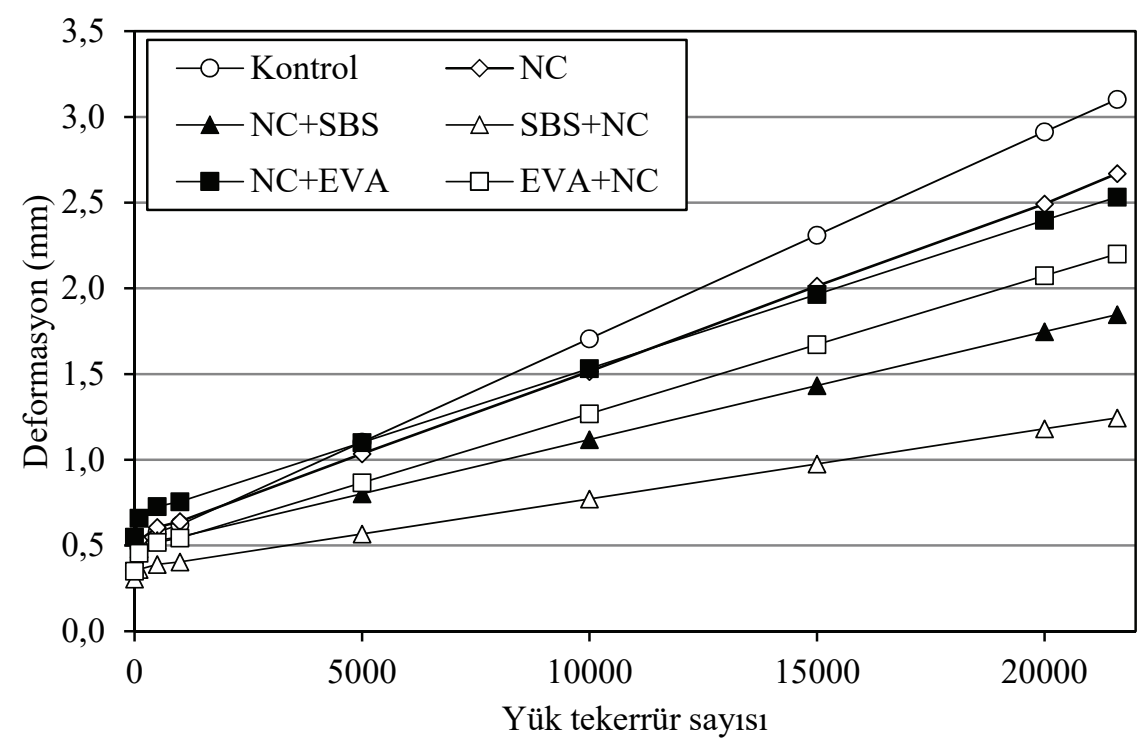

Şekil 9 - Kontrol ve modifiye karışımlar için sünme deformasyonu eğrileri

Şekil 9'da sunulan deformasyon eğrileri değerlendirildiğinde, gerek nanokil modifikasyonu ve gerek se polimerlerle elde edilen nanokompozit uygulamasının kontrol karışımlara kıyasla daha yüksek deformasyon dirençleri ortaya koyduğu görülmüştür. 21,600 yükleme tekerrür sayısından sonra oluşan deformasyonlar göz önüne alındığında; kontrol karışımlara göre NC modifikasyonunda \%14, EVA ile hazırlanan nanokompozitlerde en az \%18 ve SBS ile hazırlanan nanokompozitlerde de en az \%40 azalma görülmüştür. Aynı zamanda tekrarlı yük 
test sonuçlarının polimer-nanokil-bitüm hazırlama sürecinde polimer ve nanokilin katılma sırasından etkilendiği anlaşılmıştır. Bitüme öncelikle polimerin daha sonra nanokilin ilave edilmesi ile daha yüksek deformasyon dirençlerinin oluştuğu görülmüştür. Koşullandırma işlemi uygulanmış örnekler üzerinde katkıların etkinlikleri daha iyi yorumlanabilmektedir. Koşullandırılmamış örneklerde birbirine çok yakın değerler verebilen karışımların koşullandırma ile birlikte performans farklılıkları da artabilmektedir. Bu deney kapsamında koşullandırılmış örneklerin kullanılması sünme eğrileri arasındaki alanların büyümesine ve buna bağlı olarak farklılı̆̆ı kolaylıkla yorumlanabilmesine yardımcı olduğu düşünülmektedir.

\subsection{Fransız Tekerlek İzi Deneyi}

Asfalt karışımların tekerlek izi potansiyelleri tekrarlı yük sünme deneyine ek olarak Fransız tekerlek izi deneyi ile de değerlendirilmiştir. Deneyde kullanılan örneklerin yoğunlukları Şekil 10'da ve deformasyon eğrileri Şekil 11'de sunulmuştur.

Fransız tekerlek izi testinde sıkıştırılan örneklerin yoğunluk değerleri birbirine çok yakındır. Modifikasyonun etkisiyle, bitüme ilave edilen NC ve polimer katkılar bitümün viskozitesini arttırdığından sıkıştırmadan kaynaklanan, yoğunluk değerlerinde çok küçük azalmalar görülmüştür.

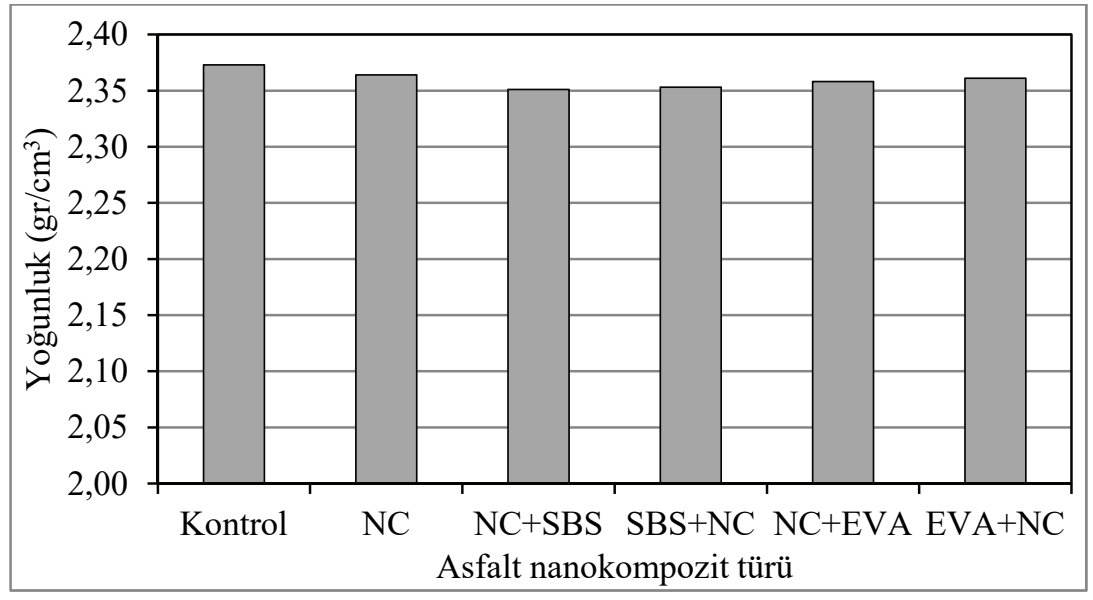

Şekil 10 - Asfalt karışım örneklerinin yoğunluk değerleri

KGM teknik şartnamesine göre 30,000 devir sayısında en fazla \%6 tekerlek izi oranı kabul edilmektedir. Şartname kriterine göre kontrol karışımlar da dahil olmak üzere bütün karışımların deformasyon koşulunu sağladığı görülmüştür. Gerek nanokil kullanımında ve gerekse polimer-nanokil/bitüm nanokompozit kullanımında kontrol karışımlara göre tekerlek izi oranının azaldığ 1 görülmüştür. 50,000 devir sayısında kontrol karışımlar \%2.56, NC modifiye bitümlü karışımlar \%2.21, EVA ile oluşturulan nanokompozitler en fazla \%1.89 ve SBS ile oluşturulan nanokompozitli karışımlar ise en çok \%1.44 tekerlek izi oranları ortaya koymuştur. SBS/nanokil/bitüm nanokompozitler EVA/nanokil/bitüm nanokompozitlere göre 
deformasyon direnci açısından daha yüksek performans sergilemiştir. Bununla birlikte, SBS ile hazırlanan nanokompozitlerde bitüme önce nanokilin katıldığı durumda, EVA ile hazırlanan nanokompozitlerde ise bitüme önce EVA plastomerinin katıldığı durumda daha yüksek tekerlek izi dirençleri görülmüştür.

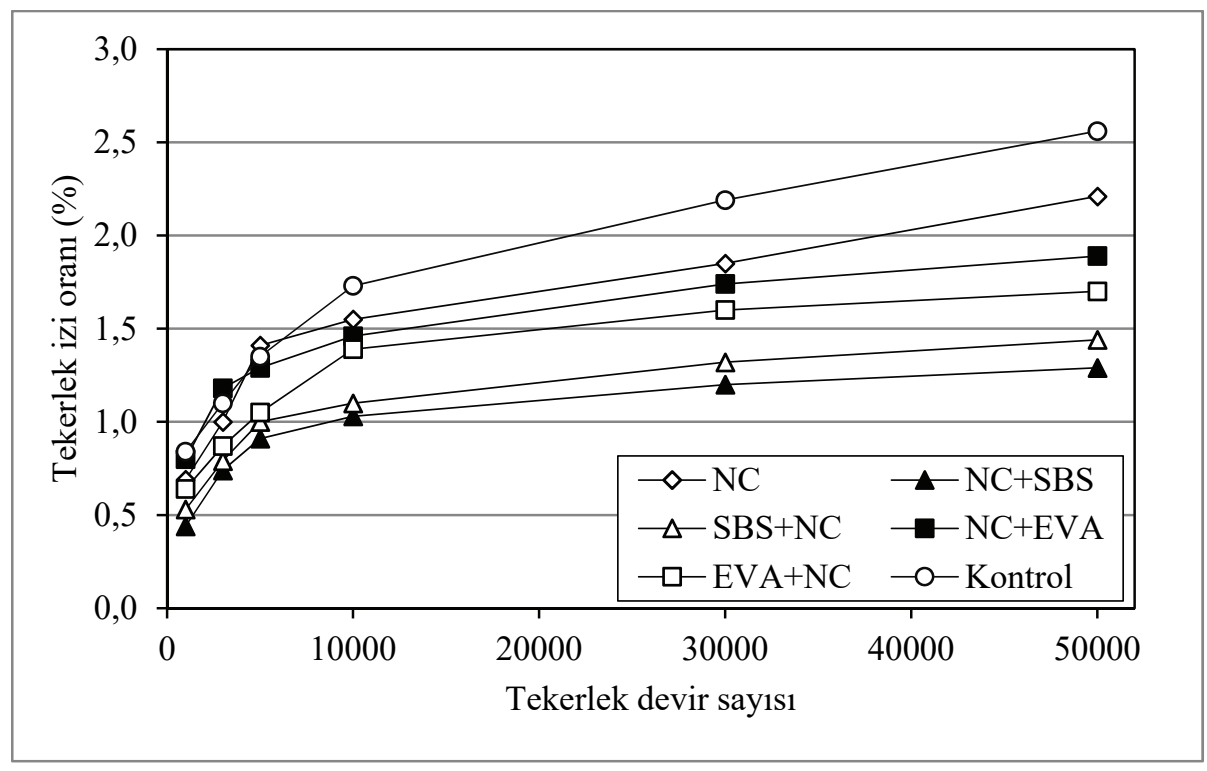

Şekil 11 - Kontrol ve nanokompozit modifiye asfalt karışımlar için tekerlek izi oranları

SBS modifiye bitümlere üçüncü bileşen olarak sıcak karıştırma yöntemi ile nanokil ilavesinin etkisinin araştırıldığı bir çalışmada nanokil ilavesi ile modifiye bitümün viskozitesinin arttığı, daha yüksek kompleks modül ve daha düşük faz açısının oluştuğu ve böylece deformasyon direnci daha yüksek ve daha elastik bağlayıcı elde edilebilmektedir. Nanokil/SBS modifiye asfalt karışımlar kontrol karışımlara göre daha yüksek tekerlek izi dayanımı göstermektedir [45]. Bir başka çalışmada da EVA modifiye bitüm ile EVA nanokompozitler karşılaştırılmış ve nanokompozit oluşturulması durumunda daha iyi mekanik özellikler elde edilmiştir [46].

Polimer/nanokil/bitüm üçlü kombinasyon kullanımı asfalt karışım modifikasyonu için yeni bir konudur. Polimer modifiye asfalt nanokompozit olarak adlandırılan bu kombinasyonda polimer ve nanokil bitüme ayrı ayrı katılabildiği gibi birlikte de katılabilmektedir. Karıştırma yöntemleri reolojik özellikleri önemli derecede etkilemektedir [20].

\subsection{Düşük Sıcaklık Dolaylı Çekme Mukavemeti Deneyi}

Asfalt karışımların düşük sıcaklık çatlama özelliklerinin değerlendirilebilmesi için dolaylı çekme mukavemeti deneyi $-10^{\circ} \mathrm{C}$ sıcaklıkta yapılmıştır. Deneyde koşullandırılmamış ve 
AASHTO T283 sistemine göre koşullandırılmış Marshall briketleri kullanılmıştır. Deney sonuçları Şekil 12'de gösterilmiştir.

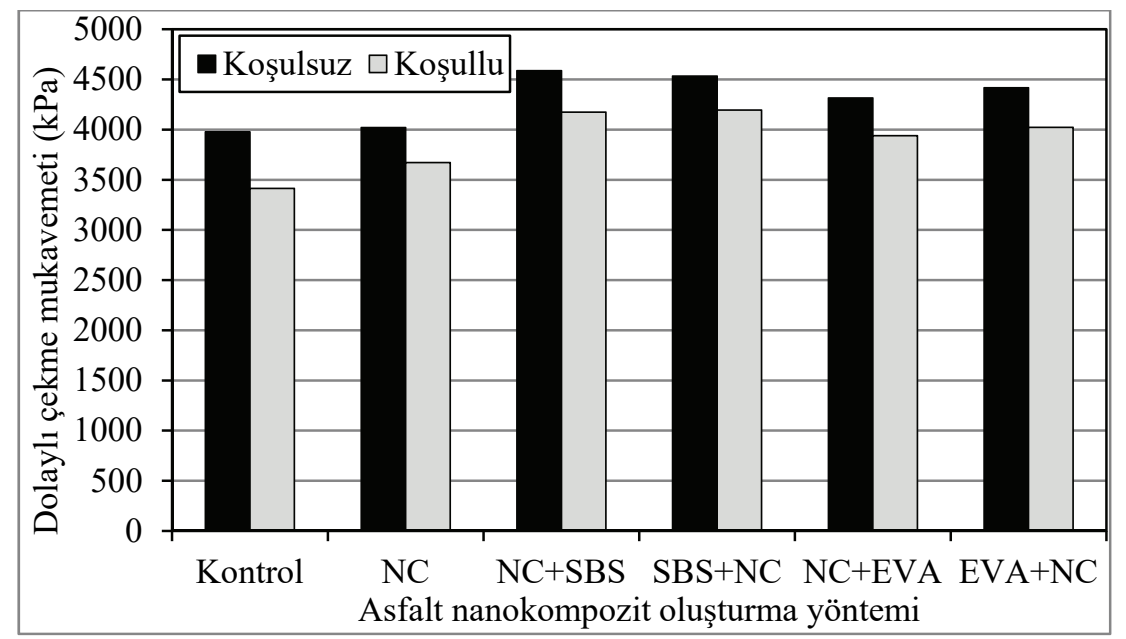

Şekil 12 - Nanokompozit oluşturma yönteminin düşük sıcaklık çatlama direnci üzerindeki etkisi

Nanokil modifiye karışımlar kontrol karışımlarla karşılaştırıldığında, koşullandırılmamış durumda çekme mukavemetlerinde çok küçük artış sağlamıştır. Koşullandırma ile birlikte modifikasyonun etkisi daha iyi görünmüştür. Bütün polimer/nanokil/bitüm nanokompozit seçenekleri yalnızca nanokil modifikasyonu ve kontrol bitüm seçeneklerinden daha yüksek çekme mukavemetleri dolayısıyla daha yüksek çatlama dirençleri göstermiştir. SBS ile hazırlanan nanokompozitlerde, bitüme önce NC katıldığı durumda koşullandırılmamış örnekler daha yüksek çekme mukavemetleri gösterirken koşullandırılmış durumda bitüme önce SBS ilave edilmesi ile daha yüksek değerler elde edilmiştir. EVA ile hazırlanan nanokompozitlerde ise hem koşullandırılmış hem de koşullandırılmamış durumda bitüme öce EVA polimerinin katılması çekme mukavemeti değerini arttırmıştır. SBS kullanılarak oluşturulan asfalt nanokompozitler EVA kullanılarak oluşturulan asfalt nanokompozitlerden oluşturulma yönteminden bağımsız olarak daha yüksek çatlama dirençleri göstermiştir.

Organik modifiye bentonit kilinin asfalt modifiyeri olarak çeşitli oranlarda çalışıldığı araştırmada sıcak ekleme yöntemi ile modifikasyon yapıldı. Modifiye bağlayıcının yumuşama noktası, viskozite ve düktilitesinin arttığı görüldü. Dinamik kesme reometresi test sonuçlarına göre, modifiye bağlayıcının deformasyon direncinin arttığı, kısa ve uzun dönem yaşlandırma prosedürlerinden sonra yapılan kiriş eğilme reometresi test sonuçlarına göre çatlama direncinde önemli artış olduğu ifade edilmektedir [47].

Polimer modifiye asfalt nanokompozitlerin fiziksel ve mekanik özelliklerinin araştırıldığı bir çalışmada kontrol bitüm ile karşılaştırıldığında depolama stabilitesi ve yaşlanma direncinin arttığı karışımın tekerlek izi ve termal çatlama direncinin iyileştiği görüldü [48]. Bitüm modifikasyonunda nanokil ilavesinin düşük sıcaklık çatlaması üzerinde olumlu bir etkisi vardır. Aynı zamanda tekerlek izi direncini de arttırmaktadır [49]. Polimer modifiye asfalt 
nanokompozitler nanokil modifikasyonuna ve polimer modifikasyonuna göre daha gelişmiş mekanik özellikler sunabilir. Ancak modifikasyon sürecinde nanokompozit oluşturma yöntemi, katılma sırası ve parametreleri, kullanılan polimer türü nihai asfalt karışımın mekanik özelliklerini etkilemektedir. Bu süreçlerin araştırılarak kontrol altında tutulması modifikasyon başarımını arttırabilir.

\section{SONUÇLAR}

Bu çalışmada, polimer modifiye asfalt nanokompozit (PMAN) üretiminde polimer ve nanokil eklenme sıralarının nihai asfalt karışım performansı üzerindeki etkisi araştırılmıştır. SBS ve EVA polimerleri nanokil ile birlikte katılma sıraları değiştirilerek yüksek sıcaklıkta karıştırma tekniği ile bitüme ilave edilmiştir. Asfalt karışımlar su hasarı, tekerlek izi, düşük sıcaklık çatlaması yönleriyle değerlendirilmiştir.

Polimer modifiye asfalt nanokompozitlerle hazırlanan asfalt karışımlar tekerlek izi direnci, su hasar direnci ve termal çatlama direnci açısından gerek modifiye edilmemiş bitümle ve gerekse nanokil ile modifiye edilmiş bitümle hazırlanan karışımlardan daha iyi özellikler göstermiştir. Nanokil modifiye bitümlü karışımlar modifiye edilmemiş bitümlü karışımlara göre daha yüksek su hasarı ve deformasyon direnci göstermiştir. Düşük sıcaklık çatlaması açısından, modifiye edilmemiş bitüm ve nanokil modifiye bitüm ile hazırlanan koşullandırılmamış karışımlardan yaklaşık olarak eşdeğer sonuçlar elde edilmiş olmasına rağmen koşullandırılmış karışımlarda nanokil modifiye bitümlü karışımlar daha yüksek çatlama dirençleri göstermiştir. Bu özellikler literatürle benzerlik göstermektedir. Nanokil modifikasyonunun bitümün viskozitesini arttırması, penetrasyon ve düktilitesini azaltması bitümün sertleşmesine ve çekme dayanımının düşmesinde neden olarak çatlama direncini düşürebilir veya olumlu bir etki oluşturmayabilir [50-51]. Ancak nanokilin hidrofobik özelliği, modifiye edilmemiş bitümle karşılaştırıldığında, nanokil modifiye bitümlü karışımın koşullandırma prosedüründen daha az etkilenmesini sağlayarak koşullandırılmış durumda termal çatlaklara karşı daha yüksek dirençler oluşturmuş olabilir.

PMAN üretim sürecinde nanokil ve polimer bileşenlerinin bitüme katılma sıraları asfalt karışımların mekanik özelliklerini etkilemektedir. EVA kullanılarak üretilen PMAN seçeneklerinde bitüme önce EVA eklenmesi durumunda seçilen deney yöntemleri ile su hasarı, deformasyon ve düşük sıcaklık çatlamasına karşı daha yüksek dirençler oluşmaktadır. Deney sonuçlarına göre, önce bitüm EVA birlikteliğinin sağlanması ardından üçüncü bileşen olarak nanokil ilave edilmesi ile daha yüksek mekanik özellikler elde edilebilmektedir.

SBS ile hazırlanan PMAN kullanıldığında, nanokil ve SBS katkılarının bitüme katılma sıraları düşük sıcaklık çatlama direnci açısından önemli bir etki oluşturmamıştır. Su hasarı ve Fransız tekerlek izi deneyi ile yapılan tekerlek izi değerlendirmesine göre bitüme önce nanokilin ardından SBS'in katılması daha yüksek performans sağlamıştır. Bununla birlikte tekrarlı yük sünme deneyinde SBS'in önce katılması daha yüksek deformasyon dirençleri oluşturmuştur.

PMAN üretiminde SBS ve EVA polimerlerinin kullanılması nihai asfalt karışımın mekanik özellikleri açısından farklı sonuçlar ortaya koymuştur. Su hasarı, deformasyon ve termal çatlama dirençleri yönüyle en yüksek değerler SBS ile hazırlanan PMAN'lerden elde edilmiştir. Nanokil ve polimerin bitüme katılma sıralarının değiştirildiği her iki seçenekte de 
SBS polimeri kullanılan seçenekler EVA polimeri kullanılan seçeneklerden daha yüksek termal çatlama ve tekerlek izi direnci göstermiştir.

$\mathrm{Bu}$ çalışmada, polimer ve nanokil katkılarının bitüme ilave edilme sıralarının nihai asfalt karışım üzerindeki etkisi araştırılmıştır. Sonraki çalışmalarda, polimer ve nanokilin bitüme katılma sıraları değiştirilerek hazırlanacak polimer modifiye asfalt nanokompozitlerin reolojik ve morfolojik özellikleri ile depolama stabilitelerinin araştırılması ve değişik polimer ve nanokil türlerinin denenmesi araştırılabilir.

\section{Semboller}

AASHTO : Amerikan Devlet Karayolu ve Taşımacılık İdareleri Birliği

EVA : Etilen vinil asetat

LCPC : Köprü ve karayolları merkez laboratuvarı

NC : Nanokil

PMA : Polimer modifiye asfalt

PMAN : Polimer modifiye asfalt nanokompozit

SBS : Stiren bütadiyen stiren

TMA : Taş mastik asfalt

TSR : Çekme mukavemeti oranı

\section{Teşekkür}

Bu çalışma Karadeniz Teknik Üniversitesi Bilimsel Araştırma Projeleri Birimi (Proje kodu: 9542) tarafindan desteklenmiştir.

\section{Kaynaklar}

[1] Tabatabaee, H. A., Bahia, H. U. Life cycle energy and cost assessment method for modified asphalt pavements. Procedia-Social and Behavioral Sciences, 54, 1220-1231, 2012.

[2] Golestani, B., Nama, B.H., Nejad, F.M., Fallah, S. Nanoclay application to asphalt concrete: Characterization of polymer and linear nanocomposite-modified asphalt binder and mixture, Construction and Building Materials 91, 32-38, 2015.

[3] You, Z., Mills-Beale, J., Foley, J.M., Roy, S., Odegard, G.M., Dai, Q., Goh, S.W. Nanoclay-modified asphalt materials: Preparation and characterization, Construction and Building Materials 25, 1072-1078, 2011.

[4] Şengöz, B., Topal, A., Işıkyakar, G. Morphology and image analysis of polymer modified bitumens, Construction and Building Materials 23, 1986-1992, 2009. 
[5] Durrieu, F., Farcas, F., Mouillet, V. The influence of UV aging of a styrene/butadiene/styrene modified bitumen: comparison between laboratory and on site aging, Fuel 86, 1446-1451, 2007.

[6] Zhu, J., Birgisson, B., Kringos, N. Polymer modification of bitumen: advances and challenges, European Polymer Journal 54, 18-38, 2014.

[7] Yusoff, N. I. M., Breem, A. A. S., Alattug, H. N., Hamim, A., Ahmad, J. The effects of moisture susceptibility and ageing conditions on nano-silica/polymer-modified asphalt mixtures. Construction and Building Materials, 72, 139-147, 2014.

[8] Bala, N., Kamaruddin, İ., Napiah, M., Sutanto, M.H. Polymer Nanocomposite Modified Asphalt: Characterisation and Optimisation Using Response Surface Methodology, Arabian Journal for Science and Engineering 44, 4233-4243, 2019.

[9] Oner, J. Examination of storage stability behaviour of polymer modified bitumen involving nanoclay. Eurasian Journal of Civil Engineering and Architecture EJCAR, 3, 49-55, 2019.

[10] Jasso, M., Bakos, D., MacLeod, D., Zanzotto, L. Preparation and properties of conventional asphalt modified by physical mixtures of linear SBS and montmorillonite clay, Construction and Building Materials 38, 759-765, 2013.

[11] Farias, L. G. A., Leitinho, J. L., Amoni, B. D. C., Bastos, J. B., Soares, J. B., Soares, S. D. A., de Sant'Ana, H. B. Effects of nanoclay and nanocomposites on bitumen rheological properties. Construction and building materials, 125, 873-883, 2016.

[12] Mohammadiroudbari, M., Tavakoli, A., Aghjeh, M. K. R., Rahi, M. Effect of nanoclay on the morphology of polyethylene modified bitumen. Construction and Building Materials, 116, 245-251, 2016.

[13] Galooyak, S. S., Dabir, B., Nazarbeygi, A. E., Moeini, A. Rheological properties and storage stability of bitumen/SBS/montmorillonite composites. Construction and Building Materials, 24(3), 300-307, 2010.

[14] Golestani, B., Nejad, F. M., Galooyak, S. S. Performance evaluation of linear and nonlinear nanocomposite modified asphalts. Construction and Building Materials, 35, 197-203, 2012.

[15] Sureshkumar, M. S., Filippi, S., Polacco, G., Kazatchkov, I., Stastna, J., Zanzotto, L. Internal structure and linear viscoelastic properties of EVA/asphalt nanocomposites. European Polymer Journal, 46(4), 621-633, 2010.

[16] Alexander, M., Dubois, P. Polymer-layered silicate nanocomposites: preparation, properties and uses of a new class of materials. Materials Science and Engineering: R: Reports 28(1-2), 1-63, 2000.

[17] Gupta, R,K,, Pasanovic-Zujo. V., Bhattacharya, S.N. Shear and extensional rheology of EVA/layered silicate-nanocomposites. Journal of Non-Newtonian Fluid Mechanics, 128(2-3), 116-25, 2005. 
[18] Martinho, F. C., Farinha, J. P. S. An overview of the use of nanoclay modified bitumen in asphalt mixtures for enhanced flexible pavement performances. Road Materials and Pavement Design, 20(3), 671-701, 2019.

[19] Krishnamoorti, R., Yurekli, K. Rheology of polymer layered silicate nanocomposites. Current Opinion in Colloid \& Interface Science 6(5-6), 464-470, 2001.

[20] Polacco, G., Kříž, P., Filippi, S., Stastna, J., Biondi, D., Zanzotto, L. Rheological properties of asphalt/SBS/clay blends. European Polymer Journal, 44(11), 3512-3521, 2008.

[21] Polacco, G., Filippi, S., Merusi, F., Stastna, G. A review of the fundamentals of polymer-modified asphalts: Asphalt/polymer interactions and principles of compatibility. Advances in colloid and interface science, 224, 72-112, 2015.

[22] Austroads Technical Report. Stone mastic asphalt surfacing. AAP asphalt guide, 2002.

[23] General Directorate of Highways of Turkey, Highway Technical Specifications, General Directorate of Highways of Turkey, Ankara, Turkey, 2013.

[24] Airey, G. D. Rheological evaluation of ethylene vinyl acetate polymer modified bitumens. Construction and Building Materials, 16(8), 473-487, 2002.

[25] Kraton, Kraton D1192 E Polymer Data Document, K0523 Europe, 2020. (https://kraton.com/products/pdsDocs/polymer/D1192E.pdf? (Erişim Tarihi: 16.06.2020)

[26] DOW Chemical Company, ELVAX ${ }^{\mathrm{TM}} 420$ Ethylene Vinyl Acetate Copolymer Technical Data Sheet, Version 215.0, 2019.

[27] Iskender, E. Evaluation of mechanical properties of nano-clay modified asphalt mixtures. Measurement, 93, 359-371, 2016.

[28] Goh, K. L., Thomas, S., De Silva, R. T., Aswathi, M. K. Interfaces in Particle and Fibre Reinforced Composites: Current Perspectives on Polymer, Ceramic, Metal and Extracellular Matrices. Woodhead Publishing, 2019.

[29] Ezzat, H., El-Badawy, S., Gabr, A., Zaki, E. S. I., Breakah, T. Evaluation of asphalt binders modified with nanoclay and nanosilica. Procedia Engineering, 143, 1260-1267, 2016.

[30] AASHTO. Standard method of test for resistance of compacted hot mix asphalt (HMA) to moisture-induced damage. AASHTO guide, 2007.

[31] Gandhi, T., Xiao, F., Amirkhanian, S. N. Estimating indirect tensile strength of mixtures containing anti-stripping agents using an artificial neural network approach. International Journal of Pavement Research and Technology, 2(1), 1-12, 2009.

[32] Lin, J., Chen, M., Wu, S. Utilization of silicone maintenance materials to improve the moisture sensitivity of asphalt mixtures. Construction and Building Materials, 33, 1-6, 2012.

[33] Asphalt Institute. Mix design methods for asphalt concrete, manual series no. 2, (MS2), 6th ed., US, 1993. 
[34] Khodaii, A., Tehrani, H. K., Haghshenas, H. F. Hydrated lime effect on moisture susceptibility of warm mix asphalt. Construction and Building Materials, 36, 165-170, 2012.

[35] Aksoy, A., Şamlioglu, K., Tayfur, S., Özen, H. Effects of various additives on the moisture damage sensitivity of asphalt mixtures. Construction and Building Materials, 19(1), 11-18, 2005.

[36] Özen, H. Rutting evaluation of hydrated lime and SBS modified asphalt mixtures for laboratory and field compacted samples, Construction and Building Materials, 25(2), 756-765, 2011.

[37] Irfan, M., Ali, Y., Iqbal, S., Ahmed, S., Hafeez, I. Rutting evaluation of asphalt mixtures using static, dynamic, and repeated creep load tests. Arabian Journal for Science and Engineering, 43(10), 5143-5155, 2018.

[38] Sarsam, S., Al-Delfi, K. Assessing Tensile Strength and Temperature Susceptibility of Asphalt Concrete. Applied Research Journal ARJ, 1, 279-287, 2015.

[39] Krcmarik, M., Varma, S., Emin Kutay, M., Jamrah, A. Development of predictive models for low-temperature indirect tensile strength of asphalt mixtures. Journal of Materials in Civil Engineering, 28(11), 04016139, 2016.

[40] SHRP. Standard Practice for Simulating the Short-Term Ageing of Bituminous Mixtures Using Forced Draft Oven, SHRP No. 1025, Strategic Highway Research Program, National Research Council, Washington, D.C., 1992.

[41] Sarsam, S. I., Alwan, A. H. Impact of Aging on Shear, Tensile Strength and Permanent Deformation of Superpave Asphalt Concrete. International Journal of Scientific Research in Knowledge, 2(10), 487-496, 2014.

[42] Hossain, Z., Zaman, M., Hawa, T., Saha, M. C. Evaluation of moisture susceptibility of nanoclay-modified asphalt binders through the surface science approach. Journal of Materials in Civil Engineering, 27(10), 04014261, 2015.

[43] Ghasemi, M., Marandi, S. M., Tahmooresi, M., Kamali, J., Taherzade, R. Modification of stone matrix asphalt with nano-SiO2. Journal of Basic and Applied Scientific Research, 2(2), 1338-1344, 2012.

[44] Goh, S. W., Akin, M., You, Z., Shi, X. Effect of deicing solutions on the tensile strength of micro-or nano-modified asphalt mixture. Construction and Building Materials, 25(1), 195-200, 2011.

[45] Yu J, Wang L, Zeng X, Li B. Effect of montmorillonite on properties of styrenebutadiene-styrene copolymer modified bitumen. Polymer Engineering Science;47(9), 1289-1295, 2007.

[46] La Mantia, F. P., Dintcheva, N. T. EVA copolymer-based nanocomposites: Rheological behavior under shear and isothermal and non-isothermal elongational flow. Polymer testing, 25(5), 701-708, 2006. 
[47] Zare-Shahabadi, A., Shokuhfar, A., Ebrahimi-Nejad, S. Preparation and rheological characterization of asphalt binders reinforced with layered silicate nanoparticles, Construction and Building Materials, 24(7), 1239-1244, 2010.

[48] Abdullah, M.E., Zamhari, K.A., Hainin, M.R., Oluwasola, E.A., Hassan, N.A., Yusoff, N.I. Engineering properties of asphalt binders containing nanoclay and chemical warmmix asphalt additives, Construction and Building Materials 112, 232-240, 2016.

[49] Khodary, F., Abd El-Sadek, M.S., El-Shshtawy, H.S. CaO/bitumen nanocomposite: synthesis and enhancement of stiffness properties for asphalt concrete mixtures, International Journal of Scientific \& Engineering Research 6 (1), 444-448, 2015.

[50] Jahromi, S., Ghaffarpour, K. A. Effects of nanoclay on rheological properties of bitumen binder. Construction and Building Materials, 23, 2894, 2009.

[51] Ouyang, C., Wang, S., Zhang, Y., \& Zhang, Y. Preparation and properties of styrenebutadiene-styrene copolymer/kaolinite clay compound and asphalt modified with the compound. Polymer Degradation and Stability, 87, 309-317, 2005. 